\title{
ZMIANY W POWIADAMIANIU RATUNKOWYM W POLSCE - SALDO KORZYŚCI I DEFICYTÓW
}

\begin{abstract}
Powiadamianie ratunkowe stanowi niezwykle istotne kluczowe ogniwo w łańcuchu działań, które mają na celu przyjście z pomocą przez państwowe służby do osoby, która znalazła się w sytuacji zagrażającej jej bezpieczeństwu i o taką pomoc się zwraca. Zanim do akcji wkroczą służby, wyspecjalizowani ratownicy ze swoim skomplikowanym sprzętem, konieczne jest, żeby dotarła do nich informacja o tym, co się dzieje, gdzie i kto potrzebuje pomocy. Odpowiedzi na te podstawowe pytania niesie zgłoszenie alarmowe, którego obsługa stanowi przedmiot działania systemów powiadamiania ratunkowego. Od roku 2011 w Polsce zachodzi proces zmiany sposobu obsługi zgłoszeń alarmowych z dyspozytorskiego i dyspozytorsko-operatorskiego na operatorski. W chwili pisania tego artykułu obsługa zgłoszeń alarmowych w Polsce odbywa się równolegle na wszystkie wcześniej wymienione sposoby. Osoba potrzebująca pomocy albo osoba zgłaszająca taką potrzebę na rzecz innej osoby lub innych osób może zadzwonić bezpośrednio na numery alarmowe służb ratunkowych: Policji - 997, Państwowej Straży Pożarnej - 998 i Państwowego Ratownictwa Medycznego - 999. W takiej sytuacji mamy do czynienia z obsługą zgłoszenia w systemie dyspozytorskim lub dyspozytorsko-operatorskim. Można także wykonać połączenie na numer 112 do Centrum Powiadamiania Ratunkowego. Takie połączenie zostanie obsłużone w sposób operatorski. Przedmiotem niniejszego opracowania jest analiza zalet i wad poszczególnych systemów obsługi zgłoszeń alarmowych.
\end{abstract}

Słowa kluczowe: powiadamianie ratunkowe, zgłoszenie alarmowe, obsługa, ratunek, pomoc

\section{WPROWADZENIE}

Powiadamianie ratunkowe funkcjonuje przez cały czas od chwili, kiedy pojawiły się instytucje (publiczne i prywatne podmioty, służby, straże i pogotowia), które miały za zadanie świadczyć pomoc ludziom w potrzebie. Sposoby ich działania wynikały z dostępnych możliwości przeprowadzenia akcji oraz z możliwości skutecznego nawiązywania kontaktu i pozyskania informacji o zachodzących zdarzeniach niebezpiecznych. Dawniej możliwości te, zarówno w jednym, jak i drugim zakresie, były dużo mniejsze niż obecnie. Pierwotnie do zawiadomienia pogotowia potrzebny był kontakt bezpośredni ${ }^{2}$. Po wynalezieniu łączności telefonicznej stała się ona głównym sposobem informowania służb o zagrożeniach i potrzebach niesienia przez nie pomocy ${ }^{3}$ obywatelom.

\footnotetext{
${ }^{1}$ Dr Stanisław J. Rysz, Podkarpacki Urząd Wojewódzki w Rzeszowie, Wydział Bezpieczeństwa i Zarządzania Kryzysowego, e-mail: stanisław.rysz@vp.pl

${ }^{2}$ Ktoś musiał przybiec do miejsca wyczekiwania i opowiedzieć, co się stało.

${ }^{3}$ Wraz z szybko postępującym rozwojem środków przekazu zarówno głosu, jak i obrazu, a także innych danych o stanie czynności życiowych osoby monitorowanej w trakcie realizacji działań, które mogą zawierać pierwiastek zagrożenia dla bezpieczeństwa osoby zgłaszającej lub osób i mienia będącego w obszarze zasięgu jej
} 
Wszędzie tam, gdzie dochodziło do przekazania informacji o zdarzeniu i jego ewentualnych skutkach (zgłoszenie alarmowe) do służby, która była właściwa do podjęcia działań ratowniczych, owo zgłoszenie było obsługiwane w systemie dyspozytorskim. Oznaczało to, że po usłyszeniu wiadomości strażak w remizie, policjant na posterunku czy sanitariusz w miejscu postoju ambulansu przystępował do realizacji sekwencji działań, których skutkiem było wyjechanie wozu strażackiego, policyjnego radiowozu albo ambulansu do akcji. Odbierający zgłoszenie był od razu dyspozytorem służby, która jechała z pomocą, a system określano mianem „dyspozytorski”. Dyspozytor (inaczej: oficer dyżurny, dyżurny) był (i wciąż jest) zatrudniony po to, żeby odebrał zgłoszenie, przeprowadził wywiad, ocenił sytuację i w uzasadnionych wypadkach dokonał zadysponowania konkretnych sił i środków właściwych do podjęcia działań. Osobnym zadaniem, jakie realizował, było monitorowanie przebiegu akcji i $\mathrm{w}$ razie potrzeby koordynowanie działań uzupełniających i korygujących. Taki system nadal funkcjonuje w pogotowiu ratunkowym (System Państwowe Ratownictwo Medyczne), Państwowej Straży Pożarnej i Policji. Połączenia na numery alarmowe odpowiednio: 999, 998 i 997 kierują zgłoszenia wprost do podmiotów ratunkowych. Podobnie rzecz się ma w odniesieniu do straży municypalnych i specjalistycznych pogotowi serwisowych ${ }^{4}$ : energetycznego, gazowego, wodno-kanalizacyjnego, ciepłowniczego i innych. Zalety takiego sposobu obsługi zgłoszeń alarmowych, pod warunkiem że te kierowane są do właściwych dla zdarzenia lub zagrożenia podmiotów, wiążą się dobrą znajomością rozpatrywanego zagadnienia przez osoby przyjmujące zgłoszenia, szybsze docieranie do meritum, łatwiejsze pozyskiwanie najistotniejszych informacji i uruchamianie akcji ratunkowej. Wady takiego sposobu obsługi zgłoszeń alarmowych związane są między innymi z jego małą wydajnością w przypadku napływu dużej liczby zgłoszeń w krótkim czasie. Wynika to wprost ze sposobu obsługi zgłoszenia zawierającego element dysponowania sił do realizacji związanych z nim działań. Dodatkowym czynnikiem wprowadzającym ograniczenia wydajności i skuteczności odbierania i obsługi zgłoszeń jest wielkość zespołu dyspozytorów. W praktyce w skład zespołu wchodzą 1-2 osoby na stanowisku dysponowania 5

Jeśli jednak zdarzyło się, że na przykład strażak odebrał wiadomość, która dotyczyła potrzeby pomocy nie ze strony straży pożarnej, ale policji albo pogotowia ratunkowego, to mając dostęp do telefonu, przekazywał wiadomość do właściwej służby, żeby ta mogła podjąć działanie. Był wtedy operatorem pośredniczącym w przekazywaniu zgłoszenia alarmowego między zgłaszającym potrzebę udzielenia pomocy a służbą właściwą do jej udzielenia. Taki system funkcjonował przez dziesięciolecia. Jego zaletą było dobre rozpoznanie przez dyspozytorów środowiska, na którego rzecz działali, i obszaru, na którym podejmowane były akcje.

Wraz z początkiem XXI wieku, a zwłaszcza po wstąpieniu Polski w struktury Unii Europejskiej (UE), pojawiła się potrzeba ujednolicenia numeru alarmowego, który miałby być identyczny w każdym kraju UE. Ten numer to ciąg cyfr: „1”, „1”, i „2”. Jest bardzo

działania, coraz częściej spotyka się próby stworzenia systemu powiadamiania o występowaniu niekorzystnych zmian. Przykłady: systemy monitoringu sytuacji pożarowej w obiektach magazynowych oraz system eCall w Polsce obowiązkowy w samochodach produkowanych od 2018 r.

4 Przykłady numerów alarmowych we Wrocławiu: http://www.wroclaw.pl/telefony-alarmowe-zaufaniainfolinie-we-wroclawiu, (dostęp: 9.12.2015).

${ }^{5} \mathrm{Na}$ podstawie informacji pozyskanych przy okazji realizacjo obowiązków zawodowych. 
prosty i nawet dziecko może go zapamiętać. Takie właśnie było założenie ${ }^{6}$, żeby nawet dziecko zapamiętało.

Do obsługi zgłoszeń na numer alarmowy 112 na początku wdrażano strażaków albo policjantów, którzy realizowali je na swoich stanowiskach we właściwych komendach powiatowych/miejskich, a miejsce ich pracy określano mianem Centrum Powiadamiania Ratunkowego.

Ze względu na to, że odbierający zgłoszenia kierowane na ten numer byli od razu dyspozytorami zasobów własnej służby albo operatorami, którzy przekazywali połączenie do pozostałych podmiotów - system obsługi zgłoszeń określano jako „operatorskodyspozytorski”.

Od roku 2011 trwają w Polsce prace mające na celu wdrożenie systemu czysto operatorskiego, czyli takiego, który będzie działać na zasadzie call center. Operatorzy numerów alarmowych (ONA) odbierają zgłoszenia alarmowe wyposażeni w nowoczesne narzędzia teleinformatyczne, przeprowadzają krótki wywiad z dzwoniącym i wybierają właściwą służbę lub właściwe służby (jeśli potrzeba ich więcej), do których przekazują odebrane zgłoszenie.

Takie podejście ma na celu znaczące ułatwienie zwracania się o pomoc zarówno obywatelom, jak i obcokrajowcom, którzy przebywają w Polsce. Pozwala istotnie poprawić sprawność obsługi zgłoszeń, filtrować zgłoszenia niezasadne i złośliwe, a także umożliwia unikanie sytuacji, kiedy niektórzy spośród obywateli byli wykluczeni ${ }^{7}$ z możliwości korzystania ze swoich praw ubiegania się o pomoc państwa w sytuacji zagrożenia ich życia, zdrowia, bezpieczeństwa albo jednocześnie kilku z wymienionych.

Istotne znaczenie dla podjęcia i znaczącego przyspieszenia działań miał zaplanowany na rok 2012 międzynarodowy turniej - Mistrzostwa Europy w Piłce Nożnej Euro 2012. Określenie „międzynarodowy” ma tu podwójne znaczenie. Z jednej strony dotyczy uczestniczących zespołów, które reprezentowały 16 europejskich krajów, a z drugiej oznacza imprezę zorganizowana na boiskach piłkarskich w Polsce $i$ na Ukrainie. W efekcie prowadzonych szeroko zakrojonych prac przygotowawczych i organizacyjnych nastąpiła wyraźna intensyfikacja działań nad wdrożeniem nowego, wydajnego i dostępnego dla obcokrajowców nieposługujących się językiem polskim systemu powiadamiania ratunkowego (SPR). Wprawdzie od kilku lat obowiązywała zmieniona Ustawa z 24 sierpnia 1991 r. o ochronie przeciwpożarowej (Dz.U. Nr 191, poz. 1410 ze zm.), w której treści zawarto zapisy ${ }^{8}$ dotyczące tworzenia i funkcjonowania systemu powiadamiania ratunkowego $\mathrm{w}$ Polsce, ale działania podjęte przez Ministerstwo Administracji i Cyfryzacji nie przystawały do zapisów wspomnianej ustawy. Do zrealizowania powziętych decyzji podejmowane były działania w ramach pilotażu, który objął teren całego kraju.

\footnotetext{
${ }^{6}$ Por. Dyrektywa 2002/22/WE Parlamentu Europejskiego i Rady z 7 marca 2002 r. w sprawie usługi powszechnej i związanych z sieciami i usługami łączności elektronicznej praw użytkowników (dyrektywa o usłudze powszechnej) (Dz.U. UE L 108 z 24.4.2002, s. 51 z 24 kwietnia 2002 r.).

${ }^{7}$ Więcej na ten temat w: S.J. Rysz, Gtusi w systemie powiadamiania ratunkowego. Analiza zagadnienia z perspektywy końca roku 2014, „Zeszyty Naukowe WSIZiA w Warszawie” 30/1 (2015), s. 256-269, do pobrania ze strony: http://www.dobrauczelnia.pl/images/zeszytyNaukowe/1_30_2015/00_zn_rysz.pdf (dostęp: 15.12.2015)

${ }^{8}$ Por. ustawa z 5 grudnia 2008 r. o zmianie ustawy o ochronie przeciwpożarowej oraz niektórych innych ustaw (Dz.U. 2009 nr 11 poz. 59)
} 
Punktem zwrotnym w procesie zmian było uchwalenie przez Sejm RP Ustawy z 23 listopada 2013 r. o systemie powiadamiania ratunkowego (Dz.U. 2013 poz. 1635, ze zm.). W treści tego aktu zawarto zarówno docelowy kształt SPR, jak i harmonogram działań na kolejnych etapach jego realizacji.

\section{SYSTEM POWIADAMIANIA RATUNKOWEGO W WERSJI DYSPOZYTORSKIEJ}

Idea dyspozytorskiego systemu powiadamiania ratunkowego została zilustrowana na rysunku 1. Do dokonania zgłoszenia alarmowego w takim systemie konieczne są wiedza dotycząca służby lub podmiotu właściwego do przeprowadzenia akcji ratunkowej lub serwisowej oraz znajomość odpowiednich numerów alarmowych ${ }^{9}$. Użycie na rysunku dwóch rodzajów strzałek służy do zilustrowania specyfiki kosztów połączeń. Strzałki konturowe oznaczają połączenia bezpłatne dla osoby dzwoniącej. Strzałki wypełnione obrazują połączenia, za które osoba dzwoniąca będzie obciążona według taryfy operatora właściwej dla konkretnej usługi.

Rys. 1. Schemat działania systemu powiadamiania ratunkowego w wersji dyspozytorskiej

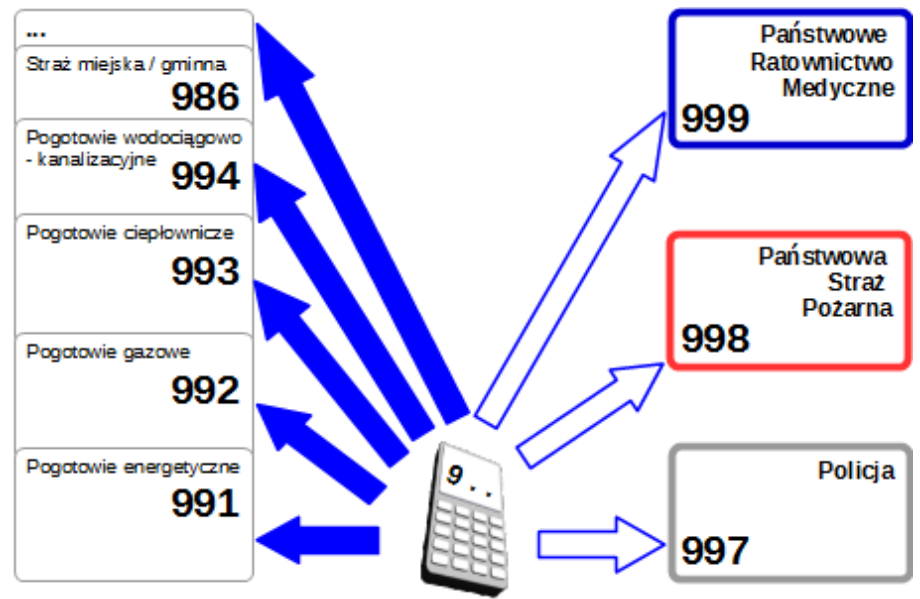

Źródło: opracowanie własne.

Specyfika systemu dyspozytorskiego polega na kierowaniu zgłoszeń alarmowych bezpośrednio do podmiotu (służby), który jest właściwy do podjęcia akcji (udzielenie pomocy, podjęcie interwencji, dokonanie naprawy itp.).

Zalety systemu dyspozytorskiego są następujące:

1) minimalna liczba połączeń między osobą zgłaszającą i podmiotem właściwym do podjęcia akcji - połączenie trafia bezpośrednio do podmiotu, który jest właściwy do zaistniałej sytuacji;

2) połączenia wykonywane do policji (997), państwowej straży pożarnej (998) oraz ratownictwa medycznego (999) są bezpłatne dla osoby dzwoniącej;

\footnotetext{
${ }^{9}$ Numery alarmowe podmiotów komercyjnych i straży municypalnej zaczerpnięto ze strony internetowej: http://www.rcit.res.pl/files/telefony_podreczne.htm (dostęp: 16.12.2015).
} 
3) dyspozytor może zadać osobie dokonującej zgłoszenia alarmowego pytania, dzięki którym w najlepszy ze swojego punktu widzenia sposób pozna sytuację i ewentualne okoliczności zdarzenia;

4) osoba dzwoniąca uzyskuje pewność, że zawiadomienie dotarło do właściwego podmiotu i pomoc lada chwila dotrze na miejsce;

5) dyspozytor może równolegle dysponować zasoby i zadawać dodatkowe pytania uzupełniające, jeśli zajdzie taka potrzeba.

Wady systemu dyspozytorskiego:

1) osoba potrzebująca pomocy musi znać numer służby, do której chce się zwrócić ${ }^{10}$;

2) duża liczba podmiotów (służb) ratunkowych i pomocowych z osobnymi numerami alarmowymi i kontaktowymi sprawia, że trzeba znać wiele różnych numerów, żeby można było nawiązać kontakt $\mathrm{z}$ właściwym i uzyskać jego pomoc ${ }^{11}$;

3) wielość podmiotów ratunkowych i serwisowych, które nie posiadają skróconych numerów, wymagają zapamiętania i wybrania prefiksu oraz 7 cyfr lokalnego numeru telefonu do podmiotu;

4) dyspozytor (dyżurny), odbierając połączenie, blokuje jednocześnie linię dla innych połączeń, które muszą czekać w kolejce ${ }^{12}$;

5) długość czasu oczekiwania na odebranie kolejnych połączeń jest sumą czasu trwania obsługiwanego połączenia alarmowego i czasu potrzebnego na podjęcie i zrealizowanie zadań związanych z zadysponowaniem zasobów domniemanych ${ }^{13}$ do właściwego przeprowadzenia akcji;

6) w sytuacji, kiedy w akcji potrzeba wykorzystać kompetencje i zasoby innego podmiotu (służby), dyspozytor musi podjąć działania mające na celu uzyskanie współdziałania ze strony takiego podmiotu ${ }^{14}$;

7) w wypadku komercyjnych usług dla ludności niekiedy biuro obsługi klientów pracuje w ciągu dnia pracy, a w godzinach popołudniowych i nocnych zgłoszenia są prze-

\footnotetext{
${ }^{10}$ Wybranie numeru innego podmiotu niż ten potrzebny do podjęcia akcji ratunkowej może zostać potraktowane jako połączenie pomyłkowe i w najlepszym wypadku, jeśli ów podmiot będzie mieć możliwość przełączenia zgłaszającego do właściwej służby, może to zrobić, blokując sobie jednocześnie możliwość odbierania zgłoszeń do czasu zakończenia przełączanego połączenia. Najczęściej jednak taka „,pomyłka” kończy się przekazaniem właściwego numeru albo stwierdzeniem odbierającego połączenie, że zagadnienie nie leży w kompetencji podmiotu, do którego zgłaszający się dodzwonił.

${ }^{11} \mathrm{~W}$ zależności od wielkości obszaru, jego skali zurbanizowania, występujących zagrożeń i działających podmiotów przykładowe listy mogą być różne i wyglądać jak na następujących, przykładowych stronach WWW: http://www.rcit.res.pl/files/telefony podreczne.htm, (dostęp: 16.12.2015), http://www.wroclaw.pl/telefonyalarmowe-zaufania-infolinie-we-wroclawiu, (dostęp: 9.12.2015), http://bezpieczna.um.warszawa.pl/kontakt/telefony-alarmowe, (dostęp: 21.12.2015), http://www.waznetelefony.pl/, (dostęp: 21.12.2015).

${ }^{12}$ Zarówno numery lokalne, jak i numery skrócone nadpisane nad numerami podkładowymi działają przy wykorzystaniu łączą telefonicznego zdefiniowanego pod siedmiocyfrowym numerem poprzedzonym lokalnym prefiksem. Każde zajęcie takiej linii do prowadzenia rozmowy uniemożliwia jej wykorzystanie do podjęcia innego połączenia.

${ }^{13}$ Autor użył w tym miejscu słowa „domniemany” do podkreślenia faktu, że właściwa wielkość potrzebnych do użycia sił i zasobów służby lub innego podmiotu podejmującego akcję w następstwie zgłoszenia alarmowego jest określana na miejscu zdarzenia przez dowódcę jednostki, która pierwsza dociera na miejsce akcji.

${ }^{14} \mathrm{~W}$ rozważanym tu przypadku mowa już nie o zgłoszeniu alarmowym, ale o połączeniu w ramach prowadzonej akcji ratunkowej.
} 
kierowywane na numery służbowe pracowników wskazanych do odbierania takich połączeń $^{15}$;

8) różne procedury odbioru i obsługi zgłoszeń przez podmioty dyspozytorskie ${ }^{16}$;

9) brak możliwości obsługi numeru w sytuacji, kiedy pojedynczy dyspozytor korzysta $\mathrm{z}$ przerwy na posiłek lub wychodzi do toalety ${ }^{17}$;

10) niewydolność systemu dyspozytorskiego w wypadku wielu zgłoszeń kierowanych na ten sam numer jednocześnie lub docierających w krótkich odstępach czasu ${ }^{18}$;

11) istotne prawdopodobieństwo braku możliwości obsłużenia zgłoszenia dokonanego w języku obcym ${ }^{19}$

12) wąska specjalizacja dyspozytora (dyżurnego $)^{20}$;

13) konieczność odbierania połączeń niezasadnych, wybieranych przypadkowo lub złośliwie, które blokują linie i niepotrzebnie angażują czas dyspozytora (dyżurnego);

14) różny stopień kompetencji interpersonalnych dyspozytorów (dyżurnych) ${ }^{21}$.

\section{SYSTEM POWIADAMIANIA RATUNKOWEGO W WERSJI OPERATORSKIEJ}

Dobrym przykładem operatorskiego sposobu obsługi zgłoszeń alarmowych jest system obsługi ogólnoeuropejskiego numeru alarmowego 112. Idea systemu powiadamiania ratunkowego $\mathrm{w}$ wersji operatorskiej została zilustrowana na rysunku $2^{22}$. Do dokonania zgłoszenia alarmowego w takim systemie wystarczy znać numer alarmowy obsługiwany

${ }^{15}$ Taki stan rzeczy występuje niejednokrotnie w firmach lokalnie dostarczających media (np. wodociągowych) i świadczące usługi dostępu np. do internetu. Coraz rzadziej, ale wciąż się to zdarza, że niektóre pogotowia serwisowe dużych komercyjnych dostawców mediów, rozlokowane np. w miastach powiatowych, także stosują opisaną tu praktykę.

${ }^{16} \mathrm{Nie}$ ma obowiązku stosowania przez wszystkie podmioty uczestniczące w systemie powiadamiania ratunkowego jednej spójnej i zunifikowanej procedury obsługi zgłoszeń.

${ }^{17}$ Opisane ograniczenie może wystąpić zwłaszcza w sytuacji jednoosobowego dyżuru na stanowisku dyspozytorskim. Osobno należy także zaznaczyć, że w wypadku przekierowywania zgłoszeń na telefony komórkowe zdarza się, że baterie telefonów ulegają rozładowaniu i przez to nawiązanie kontaktu i dokonanie zgłoszenia staje się albo niemożliwe, albo też znacznie utrudnione.

${ }^{18}$ Niniejsze ograniczenie (wada) dyspozytorskiego sposobu obsługi zgłoszeń alarmowych jest kompilacją wcześniej opisanych ograniczeń: blokowania linii telefonicznej, konieczności zadysponowania zasobów itp. Zagadnienie wynika ze sposobu skonstruowania łączy teleinformatycznych - 1 lub 2 linie telefoniczne mogą jednocześnie obsługiwać co najwyżej 2 połączenia, zmuszając tym samym wszystkich innych zgłaszających do oczekiwania.

${ }^{19}$ Ujęcie tego zapisu w formie tezy prawdopodobnej wynika z prawdopodobieństwa, że dyspozytor zna język obcy, w którym kierowane jest zgłoszenie. Niemniej jednak znajomość języków obcych nie stanowi kryterium doboru osób do pracy na stanowiskach dyspozytorskich.

${ }^{20}$ W wypadku ,pomyłkowego” wybrania podmiotu do podjęcia działań dyspozytor nie ma obowiązku znać struktury systemu powiadamiania ratunkowego na tyle, żeby mógł kompetentnie doradzić właściwy kompetencyjnie podmiot i podać jego numer kontaktowy.

${ }^{21}$ Brak jednolitych standardów obsługi zgłoszeń alarmowych idzie w parze z brakiem ujednolicenia wymagań zarówno co do wykształcenia, jak i co do umiejętności interpersonalnych osób, którym powierza się obowiązki obsługi zgłoszeń.

${ }^{22}$ Podobnie jak to na schemacie opisującym system dyspozytorski, strzałki konturowe na rysunku oznaczają połączenie bezpłatne dla osoby dokonującej zgłoszenie alarmowe. Strzałka szara dotyczy połączeń realizowanych niejako „wewnątrz” systemu przez podmioty stanowiące jego elementy. Dodatkową zmianą jest ukazanie na rysunku 2 podmiotów, do których kierowane sa informacje „,wewnatrz” systemu powiadamiania ratunkowego, bez numerów. Ta przestrzeń działania nie wymaga od osoby dokonującej zgłoszenia znajomości takich szczegółów. 
w centrali systemu. Do obsługi numeru alarmowego 112 taką centralą jest Centrum Powiadamiania Ratunkowego (CPR). Do CPR doprowadza się w sposób redundantny ${ }^{23}$ wiele $^{24}$ linii telefonicznych, dzięki czemu do operatorów w jednym czasie może trafić dużo więcej zgłoszeń alarmowych. Czas oczekiwania na zgłoszenie został racjonalnie zminimalizowany i wynosi tyle, ile potrzeba na przeprowadzenie sieciowych procedur ustalenia położenia geograficznego urządzenia telekomunikacyjnego, z którego realizowane jest połączenie ${ }^{25}$. System ma strukturę wielowarstwową. Opisany czas oczekiwania dotyczy warstwy wojewódzkiej, kiedy CPR przyjmuje i obsługuje zgłoszenie kierowane $\mathrm{z}$ obszaru własnego województwa. Operator numerów alarmowych zatrudniony na stanowisku obsługowym $\mathrm{w}$ CPR ma do dyspozycji urządzenia i teleinformatyczne aplikacje, które wspierają go w należytej obsłudze zgłoszeń alarmowych. Na dotykowej konsoli ekranowej niezwłocznie po odebraniu zgłoszenia system wyświetla strukturę podmiotów ratowniczych, interwencyjnych, serwisowych i pomocniczych, jakie zadeklarowały swoją współpracę z systemem powiadamiania ratunkowego $\mathrm{z}$ danego powiatu ${ }^{26}$.

W przypadku gdy liczba połączeń kierowanych do danego CPR przekracza możliwości jednoczasowej obsługi zgłoszeń uruchamia się tzw. funkcjonalność „odmiejscowiona”. Oznacza to, że takie zgłoszenie, którego oczekiwanie przekroczy czas założony w systemie (np. $90 \mathrm{~s}$ ), jest kierowane do innego CPR do operatora, który najdłużej oczekuje na zgłoszenie alarmowe. Scentralizowany system teleinformatyczny udostępnia także temu operatorowi wszelkie dane wspomagające obsługę zgłoszenia, co $\mathrm{w}$ zestawieniu ze zunifikowaną, jednolitą w całym kraju standardową procedurą obsługi zgłoszeń alarmowych sprawia, że osoba zgłaszająca może wcale się nie zorientować, że została obsłużona w miejscu położonym na drugim końcu Polski.

Operatorski sposób obsługi zgłoszeń alarmowych pozwala także (po wdrożeniu właściwych funkcjonalności) obsłużyć zgłoszenia alarmowe kierowane do SPR za pomocą wiadomości SMS. Jest to sposób szczególnie przydatny wszędzie tam, gdzie werbalny sposób kontaktu przez telefon jest utrudniony lub wręcz niemożliwy. Dotyczy to sytuacji, kiedy pomocy potrzebuje osoba niesłysząca ${ }^{27}$, poszkodowana $\mathrm{w}$ sytuacji przemocy domowej, terroryzmu lub porwania ${ }^{28}$.

Osoby, które pracują na stanowiskach operatorów numerów alarmowych w systemie powiadamiania ratunkowego, posiadają ważny certyfikat ONA, który otrzymuje się po przejściu szkolenia merytorycznego i zdania egzaminu przed komisją. Od kandydatów na

\footnotetext{
${ }^{23}$ Niezawodność i bezpieczeństwo systemu zasadniczego są dodatkowo wzmacniane przez zbudowanie drugiego alternatywnego systemu, prowadzonego osobnym szlakiem, który w wypadku awarii przejmie wszystkie funkcje systemu zasadniczego.

${ }^{24} \mathrm{~W}$ zależności od wielkości i liczby mieszkańców może to być kilka, kilkanaście lub kilkadziesiąt lączy.

${ }^{25}$ W chwili pisania tego artykułu w CPR w Rzeszowie dzwoniący oczekiwał na połączenie około 9-11 sekund.

${ }^{26}$ Ponieważ system operatorski jest jeszcze $\mathrm{w}$ fazie wprowadzania zmian, nie wszystkie wskazane tu opcje sa definitywnie wdrożone. Oznacza to, że do usprawnienia obsługi zgłoszeń niektóre podmioty serwisowe są definiowane i linkowane we własnym zakresie przez obsługę teleinformatyczną CPR

${ }^{27}$ Por. S.J. Rysz, op. cit.

${ }^{28}$ W okresie udostępniania lokalnej bramki SMS w CPR w Rzeszowie ONA stosowali łączność SMS do obsługi zgłoszeń alarmowych kierowanych z terenów o słabym zasięgu sygnału, co nie pozwalało uzyskać skutecznego połączenia werbalnego.
} 
ONA wymaga się polskiego obywatelstwa oraz znajomości przynajmniej jednego języka obcego w stopniu co najmniej komunikatywnym ${ }^{29}$.

Jednolite wymagania stawiane kandydatom na operatorów numerów alarmowych w całym kraju w połączeniu z jednolitymi standardami obsługi zgłoszeń sprawiają, że operatorzy we wszystkich centrach powiadamiania ratunkowego $\mathrm{w}$ kraju pracują podobnie, dzięki czemu obsługa zgłoszeń także odbywa się podobnie we wszystkich jednostkach CPR, co istotnie poprawia skuteczność dysponowania zasobów właściwych do prowadzenia akcji ratunkowej lub interwencji serwisowej.

Rys. 2. Schemat działania systemu powiadamiania ratunkowego w wersji operatorskiej

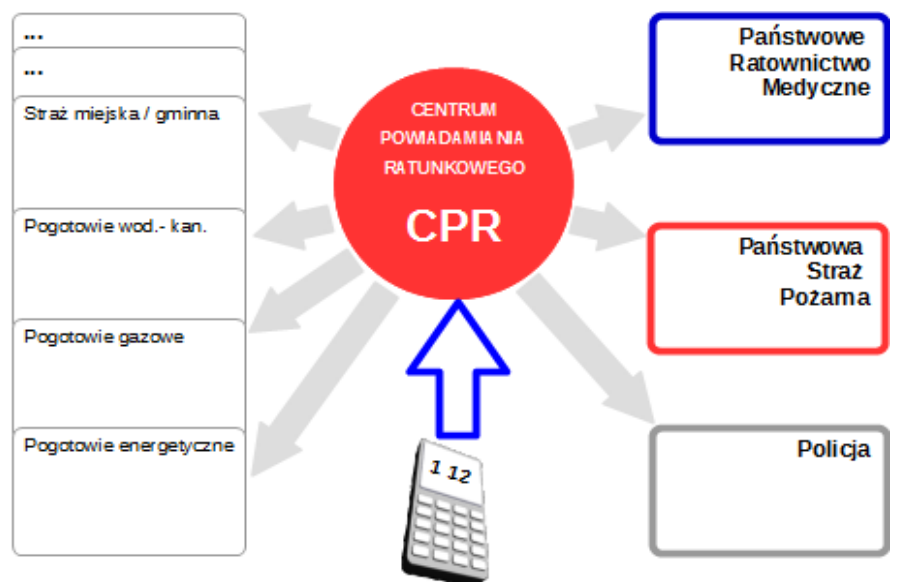

Źródło: opracowanie własne.

Zalety systemu operatorskiego:

1) jeden uniwersalny numer alarmowy do stosowania dla wszystkich rodzajów zdarzeń znacznie ułatwia zapamiętanie kontaktu z systemem powiadamiania ratunkowego i uwalnia osobę dzwoniącą, niejednokrotnie działającą pod wpływem stresu, od konieczności podejmowania decyzji ${ }^{30}$ co do rodzaju potrzebnych służb ratowniczych;

2) funkcjonalność określenia na mapie miejsca, skąd kierowane jest zgłoszenie alarmowe $^{31}$, pozwala skierować zgłoszenie do służb i podmiotów, które mają najbliżej z punktu wyczekiwania do miejsca zdarzenia, a więc mogą tam dotrzeć w najkrótszym czasie;

3) możliwość równoczesnego i równoległego zawiadamiania wielu podmiotów ratowniczych o potrzebie podjęcia przez nie akcji (z jednoczesnym wskazaniem podmiotu

\footnotetext{
${ }^{29}$ Por. art. 16 ust. 2 ustawy z 22 listopada 2013 r. o systemie powiadamiania ratunkowego.

${ }^{30}$ Odpowiednio przeszkolony, wyposażony w urządzenia i aplikacje wspierające, działający w optymalnych warunkach ONA jest w stanie po przeprowadzeniu krótkiego wywiadu co do okoliczności zdarzenia przejąć zadanie wyboru służb i odpowiednio je zawiadomić.

${ }^{31}$ Wprawdzie systemy teleinformatyczne są w stanie określić położenie telefonu, z którego wybrano numer alarmowy 112, ale w większości wypadków takie połączenie jest realizowane z bezpośredniego sąsiedztwa miejsca zdarzenia.
} 
wiodącego) $^{32}$ znacznie skraca czas od chwili otrzymania przez ONA informacji o zdarzeniu do momentu wyjazdu służb do akcji;

4) zapis audio przebiegu połączeń zgłoszeniowych pozwala monitorować prawidłowość podejmowanych decyzji i w razie potrzeby dokonywać koniecznych poprawek i uzupełnień ${ }^{33}$;

5) filtrowanie i eliminowanie ${ }^{34} \mathrm{z}$ procesu obsługi zgłoszeń niezasadnych (przypadkowych, złośliwych i pomyłkowych) i przekazywanie do podmiotów w systemie powiadamiania ratunkowego tylko zgłoszeń bezwzględnie wymagających podjęcia akcji ratunkowej, interwencyjnej lub serwisowej;

6) możliwość współpracy CPR $\mathrm{z}$ podmiotami ratunkowymi, interwencyjnymi i serwisowymi $\mathrm{z}$ terenu całego kraju ${ }^{35}$ wpisanymi w struktury $\mathrm{SPR}^{36}$. W przypadku podmiotów komercyjnych i służb publicznych innych niż Policja, Państwowa Straż Pożarna oraz dysponenci państwowego ratownictwa medycznego, uzgadniają one z dostawcami publicznie dostępnych usług telefonicznych we własnym zakresie warunki techniczne obsługi użytkowanego numeru telefonicznego oraz własnego stanowiska kierowania, które umożliwią im współpracę z systemem;

7) system urządzeń i aplikacji teleinformatycznych wspomagających ustalanie pozycji osoby dzwoniącej, okoliczności zdarzenia i podejmowanie decyzji w kwestii najbardziej optymalnego wykorzystania dostępnych zasobów sił i środków podmiotów ratowniczych, interwencyjnych i serwisowych;

\footnotetext{
${ }^{32}$ Odbywa się to przy użyciu tzw. formatki. Jest to tabelarycznie zebrany wywiad o zdarzeniu zawierajaç, oprócz informacji przekazywanych przez osobę dokonującą zgłoszenie na numer alarmowy, także dane zebrane przez automatyczne systemy wspomagajace prace operatorów w CPR. Na podstawie wywiadu ONA dobiera służbę wiodącą i służby wspomagające i po dedykowanej światłowodowej sieci teleinformatycznej „OST 112 " wysyła w jednym momencie formatkę do systemów wsparcia dowodzenia wskazanych służb. Jeśli któryś z wybranych podmiotów nie dysponuje SWD kompatybilnym z systemem wsparcia dowodzenia CPR, wtedy operator dodatkowo telefonicznie informuje taki podmiot o zaistniałej sytuacji i potrzebie podjęcia przez nią akcji.

${ }^{33}$ Taka organizacja bazy plików audio z obsługi poszczególnych zgłoszeń alarmowych zapewnia lepszą współpracę i przekazywanie nagrań z CPR do upoważnionych podmiotów, które prowadzą działania wyjaśniające w sprawach, w których użyte były zasoby służb i podmiotów stanowiących elementy SPR.

${ }^{34}$ Ze względu na to, że połączenia z numerami alarmowymi: 112, 997, 998 i 999 są bezpłatne dla osoby dzwoniącej, a także ze względu na możliwość wykonywania takich połączeń z telefonu z zablokowana klawiatura oraz pozbawionego karty SIM, bardzo często się zdarza, że osoby nieodpowiedzialne wykorzystują to i złośliwie dzwonia do CPR. Sa to połaczenia niezasadne, realizowane czasami przez dzieci posiadajace telefon komórkowy, które za darmo mogą nawiązać kontakt z kimś, kto na pewno się do nich odezwie, albo przez osoby niezrównoważone psychicznie. Są to połączenia najczęściej głuche, ale często zdarzają się także wulgarne i chamskie. Osoby nadużywajace numeru alarmowego sa zwykle przekonane, że po wyjęciu karty SIM stają się anonimowe i bezkarne. Nie zdają sobie sprawy z tego, że struktura sieci komórkowych, system identyfikacji aparatów telefonicznych i procedura logowania w stacjach bazowych pozwalają z dużą dokładnością określać zarówno tożsamość telefonu, jak i osoby, która go użytkuje.

${ }^{35}$ System teleinformatyczny zaimplementowany w Centrach Powiadamiania Ratunkowego jest struktura scentralizowaną i identyczną, co do zasady, we wszystkich ośrodkach w kraju. Oznacza to, że po przybliżeniu pozycji geograficznej miejsca, z którego jest wykonywane zgłoszenie na numer alarmowy, system wybiera automatycznie właściwy terenowo ośrodek i przedkłada na ekran konsoli operatorskiej panel dotyczący podmiotów alarmowych dostępnych w powiecie, na którego terenie nastąpiło rozpatrywane zdarzenie. Dzieje się to na każdym stanowisku w kraju, na które trafia do obsługi zgłoszenie alarmowe.

${ }^{36}$ Więcej na ten temat w art. 3 i art. 5 ustawy z dnia 22 listopada 2013 r. o systemie powiadamiania ratunkowego.
} 
8) możliwość obsługi zgłoszeń generowanych przez automatyczne systemy ${ }^{37}$ działające niezależnie od woli człowieka ${ }^{38}$;

9) system powiadamiania ratunkowego funkcjonuje w oparciu na specjalnie do tego zbudowanej, ogólnokrajowej, odseparowanej, odpowiednio zabezpieczonej i osobno zarządzanej sieci teleinformatycznej OST 112.

Wady systemu operatorskiego:

10) ograniczenie możliwości wykorzystania przez dyspozytorów znajomości terenu i ludzi, którzy ten teren zamieszkują. Taką wiedzę dyspozytorzy pozyskiwali wraz z doświadczeniem w ciągu lat pracy na swoich stanowiskach - byli doskonale zorientowani co do potencjalnej lokalizacji zgłaszanych zdarzeń ${ }^{39}$, mentalności i stanu kontaktujących się z nimi ludzi oraz przypadłości, jakie zgłaszają;

11) wzrost liczby połączeń odbieranych przez CPR i realizowanych za jego pośrednictwem, co wpływa na wzrost skumulowanej wartości połączeń telefonicznych oraz teleinformatycznych po stronie SPR;

12) bezpłatność i łatwość dostępu do SPR mogą prowokować niektóre osoby do dokonywania nieodpowiedzialnych, niezasadnych połączeń z ONA;

13) w budowie SPR brało udział wiele podmiotów komercyjnych, co może generować konflikty interesów na styku obszarów ich działań ${ }^{40}$;

14) SPR funkcjonuje na podstawie zasobów, których konfigurację, modernizację, obsługę, bieżące utrzymanie oraz konserwację wykonują podmioty komercyjne spoza sektora administracji publicznej.

\section{PODSUMOWANIE}

Przedstawiona w niniejszym opracowaniu analiza zmian w funkcjonowaniu systemu powiadamiania ratunkowego w Polsce pozwala dostrzec kilka istotnych elementów:

1) zmiany mają na celu przekształcenie SPR w system w pełni operatorski z numerem alarmowym 112;

2) docelowo możliwe będzie przeniesienie odpowiedzialności z pozostającej pod wpływem stresu osoby zgłaszającej na operatora numerów alarmowych za działania potrzebne do skutecznego powiadomienia o zaistniałym zdarzeniu właściwych kompetencyjnie podmiotów ratowniczych;

\footnotetext{
${ }^{37}$ Dobrym przykładem jest tu eCall - system automatycznego powiadamiania o kolizji drogowej, w której uczestniczył pojazd. Jest to element większej inicjatywy o wymiarze ogólnoeuropejskim opisanej w Dyrektywie Parlamentu Europejskiego i Rady 2010/40/UE w sprawie ram wdrażania inteligentnych systemów transportowych $\mathrm{w}$ obszarze transportu drogowego oraz interfejsów z innymi rodzajami transportu (Dz.U. UE L 207/1 6.8.2010 z 7 lipca 2010 r.), ze strony WWW: http://www.nettax.pl/serwis/imgpub/duuel/2010/207/1_20720100806p100010013.pdf (dostęp: 23.12.2015).

${ }^{38}$ Taką funkcję spełniają automatyczne czujniki przeciwpożarowe, instalowane w miejscach szczególnie zagrożonych pożarami lub w których skutki wystąpienia pożaru powodowałyby szczególnie dotkliwe straty. Sygnały z takich czujników, ze względu na specyfikę zagrożenia, kierowane są bezpośrednio do stanowisk kierowania Państwowej Straży Pożarnej - służby kompetentnej do gaszenia pożarów.

${ }^{39}$ Jest to szczególnie istotne przy lokalizowaniu miejsca zdarzenia, kiedy osoba zgłaszająca nie posługuje się nazewnictwem administracyjnym, ale używa nazw historycznych, tradycyjnych, zwyczajowych, lokalnych albo określeń środowiskowych (np. przysiółki).

${ }^{40}$ Inne podmioty dostarczały urządzenia, a inne oprogramowanie. To może powodować próby przerzucania odpowiedzialności za nienależyte funkcjonowania systemu pomiędzy elementami hardware’u i software’u systemu.
} 
3) SPR, przy aktywnym udziale zainteresowanych podmiotów komercyjnych, uwzględnia w przyszłości możliwość skoncentrowania w CPR kanałów komunikacyjnych związanych nie tylko z podmiotami ratowniczymi, ale także interwencyjnymi i serwisowymi, dzięki czemu znacznie skróci się i uprości lista numerów potrzebnych do zapewnienia odpowiedniego poziomu bezpieczeństwa, świadczeń i usług dostępnych dla obywateli;

4) system operatorski będzie w pełni bezpłatny dla zgłaszających;

5) wzrośnie liczba połączeń realizowanych przez CPR i za jego pośrednictwem.

$\mathrm{Na}$ rysunku 3 przedstawiono schemat powiadamiania ratunkowego w Polsce w roku 2015. Jest to efekt superpozycji jednoczesnego funkcjonowania obu wcześniej opisanych systemów. Należy tu wspomnieć, że możliwy do stosowania dyspozytorsko-operatorski sposób obsługi zgłoszeń alarmowych w praktyce nie występuje wcale lub pojawia się bardzo rzadko. Wiąże się to $\mathrm{z}$ tym, że takie przekierowanie połączenia jest równoznaczne z zablokowaniem linii telefonicznej do własnej służby na czas obsługi przekazanego zgłoszenia przez właściwy podmiot. Ograniczono się więc do podawania dzwoniącym numeru właściwego podmiotu i wskazania, że tam powinien dokonać swojego zgłoszenia.

Rys. 3. Schemat powiadamiania ratunkowego w Polsce w roku 2015

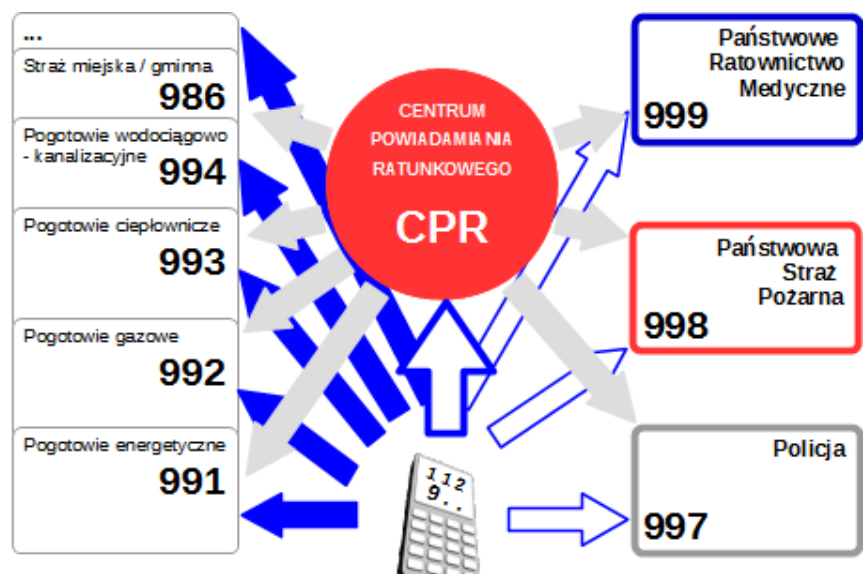

Źródło: opracowanie własne.

W przypadku gdy ów docelowy podmiot należał do listy numerów, do których połączenia były bezpłatne, osoba dzwoniąca nie musiała za takie połączenie płacić. Jeśli jednak była to instytucja spoza tej listy, wtedy na wykonanie z nią połączenia potrzebne były środki w zasobie osoby dzwoniącej. $Z$ finansowego punktu widzenia powodowało to, że część kosztów takich zgłoszeń była opłacana przez osoby zgłaszające. Dokonując zmiany sposobu obsługi zgłoszeń na operatorski, państwo i podmioty świadczące usługi w zakresie łączności telefonicznej stacjonarnej i mobilnej przejęły na siebie wszystkie koszty połączeń telefonicznych, jakie wiążą się z obsługą zgłoszeń alarmowych.

Kwestią czasu jest przejęcie przez CPR obsługi bezpłatnych resortowych numerów alarmowych $(997,998,999)$. Ustawa o systemie powiadamiania ratunkowego określa 
warunki takich zmian ${ }^{41}$ i zakreśla czasokres na ich wprowadzenie. Nawiązanie współpracy i obsługi zgłoszeń kierowanych do innych podmiotów za pośrednictwem CPR wymaga podjęcia przez te podmioty inicjatywy i spełnienia warunków wymaganych w przedmiotowej ustawie.

Zastosowanie systemu operatorskiego do obsługi zgłoszeń alarmowych stwarza nowe możliwości i otwiera nowe perspektywy świadczenia usług z zakresu niesienia pomocy w sytuacjach nie tylko niosących zagrożenie dla zdrowia, życia i mienia, ale także w sferze usług związanych z komercyjną działalnością uczestników na przykład rynku dostawców mediów.

\section{LITERATURA}

[1] Rysz S.J., Gtusi w systemie powiadamiania ratunkowego. Analiza zagadnienia z perspektywy końca roku 2014, „Zeszyty Naukowe WSIZiA w Warszawie” 30/1 (2015).

[2] Dyrektywa 2002/22/WE Parlamentu Europejskiego i Rady z 7 marca 2002 r. w sprawie usługi powszechnej i związanych z sieciami i usługami łączności elektronicznej praw użytkowników (dyrektywa o usłudze powszechnej) (Dz.U. UE L 108 z 24.4.2002, str. 51 z 24 kwietnia 2002 r.).

[3] Dyrektywa Parlamentu Europejskiego i Rady 2010/40/UE w sprawie ram wdrażania inteligentnych systemów transportowych w obszarze transportu drogowego oraz interfejsów z innymi rodzajami transportu (Dz.U. UE L 207/1 6.8.2010 z 7 lipca 2010 r.), ze strony WWW: http://www.nettax.pl/serwis/imgpub/duuel/2010/207/1_20720100806p100010013.pdf, (dostęp: 23.12.2015)

[4] Ustawa z 5 grudnia 2008 r. o zmianie ustawy o ochronie przeciwpożarowej oraz niektórych innych ustaw (Dz.U. $2009 \mathrm{nr} 11$ poz. 59 2009.02.10).

[5] Ustawa z 22 listopada 2013 r. o systemie powiadamiania ratunkowego (Dz.U. 2013 poz. 1635 ze zm.).

[6] http://www.rcit.res.pl/files/telefony_podreczne.htm, (dostęp: 16.12.2015).

[7] http://www.wroclaw.pl/telefony-alarmowe-zaufania-infolinie-we-wroclawiu, (dostęp: 9.12.2015).

[8] http://bezpieczna.um.warszawa.pl/kontakt/telefony-alarmowe, (dostęp: 21.12.2015).

[9] http://www.waznetelefony.pl/, (dostęp: 21.12.2015).

\section{CHANGES IN AREA OF RESCUE NOTIFICATION IN POLAND - BALANCE OF BENEFITS AND DEFICITS}

Emergency notification is an extremely important key link in the chain of actions that are aimed at coming by the national with help to a person who becomes in a situation threatening its security and asks for such assistance. Before the specialized service and rescue teams enter into action with their sophisticated equipment, it is required to reach information about what is happening, where it happens and to whom it happens. The answers to these fundamental questions brings a connection to emergency notification, whose handling is a subject of the operation of the emergency notification systems. Since the year 2011 in Poland this process of change way of handling emergency calls from the dispatcher's way to operator's way has occurred. At the time of writing this article, a handling of emergency calls in Poland is carried out in parallel on both of the previously mentioned ways. A person who needs assistance, or a person presenting such a need for another person or other people, can directly call emergency numbers emergency services: the Police - 997, the State Fire Service - 998 and the State Medical Rescue - 999. In such case we are dealing with a han-

\footnotetext{
${ }^{41}$ Por art. 29. ustawy o systemie powiadamiania ratunkowego, op. cit.
} 
dling of notification in dispatchers way. It may also make a call to 112 in Emergency Notification Centre. Such connections will be handled in a manner operator. The subject of this study is to analyze the advantages and disadvantages of both systems of handling emergency alerts.

Keywords: emergency notification, emergency call, service, help, assistance

\section{DOI: 10.7862/rz.2016.mmr.20}

Tekst złożono w redakcji: kwiecień 2016

Przyjęto do druku: wrzesień 2016 